\title{
EVALUASI TAHAN BANJIR PADI LOKAL SULAWESI UTARA PADA FASE VEGETATIF DENGAN VARIASI WAKTU PERENDAMAN
}

\author{
Risky Hiskia Poluan ${ }^{1)}$, Nio Song Ai ${ }^{1)}$, Feky Recky Mantiri ${ }^{1)}$ \\ ${ }^{1)}$ Program Studi Biologi, FMIPA Universitas Sam Ratulangi Manado \\ e-mail: hiskia.risky@yahoo.co.id; nio_ai@yahoo.com; fmantiri@yahoo.com
}

\begin{abstract}
ABSTRAK
Banjir merupakan salah satu kendala yang menghambat produktivitas padi. Masalah ini dapat diselesaikan dengan beberapa cara, salah satunya dengan strategi adaptasi. Oleh karena itu perlu dilakukan kajian tentang adaptasi banjir khusunya pada padi lokal Sulawesi Utara (Superwin, Burungan, Temo dan Ombong). Penelitian telah dilaksanakan untuk mengakaji pengaruh cekaman banjir terhadap padi lokal Sulawesi Utara pada fase vegetatif. Penelitian ini dilakukan dengan 4 varietas padi lokal Sulawesi Utara (Superwin, Ombong, Temo dan Burungan) dengan 12 kali ulangan dan perlakuan dilakukan pada saat padi berusia 2 minggu. Perlakuannya yaitu dengan membanjiri tanaman padi yang berusia 2 minggu hingga hari ke-20. Dari hasil penenlitian ini tinggi tanaman dari keempat varietas padi lokal Sulawesi Utara sama-sama menunjukkan pertumbuhan yang baik sehingga bisa dijadikan indikator padi yang tahan banjir. Berdasarkan jumlah daun dari keempat varietas varietas Superwin yang memiliki daun terbanyak dibanding dengan ketiga varietas lainnya, namun secara keseluruhan dari jumlah daun setiap varietas bisa bertahan dalam banjir sehingga bisa dipakai sebagai indikator padi yang tahan banjir.
\end{abstract}

Kata kunci: tinggi tanaman, jumlah daun, padi lokal Sulawesi Utara, fase vegetatif, banjir

\section{EVALUATION OF THE LOCAL FLOOD-RESISTENT RICE NORTH SULAWESI THE VEGETATIVE PHASE WITH THE VARIATION OF IMMERSION TIME}

\begin{abstract}
Flood is one of the problems that hinder rice production. This problem can be solved in several way, such as adaptation strategies. It is therefore necessary to study about the adaptation of flooding especially to the local rice of North Sulawesi (Superwin, Burungan, Temo and Ombong). This research has been conducted to assess the effect of flooding stress to the local rice of North Sulawesi on the vegetative phase. This research was conducted by four local rice varieties (i.e., Superwin, Ombong, Temo and Burungan) with 12 repetitions and treatments carried out during 2 weeks old rice. The treatment is to flood the rice plants 2 weeks old up to the 20th day. From this research, plant height for each of four local rice varieties show good growth so it can be used as indicator of flood-resistant rice. Based on the number of leaves of four varieties, Superwin has most leaves compared with the three other varieties, but overall on the number of leaves each variety can survive in flood that could be used as an indicator of flood-resistant rice.
\end{abstract}

Keywords: plant height, leaf numbers, local rice of North Sulawesi, vegetative phase, flood

\section{PENDAHULUAN}

Salah satu penyebab bencana ialah dampak perubahan iklim global di Indonesia, di antaranya tingginya curah hujan di beberapa tempat dan naiknya permukaan air laut yang mengakibatkan terjadinya banjir. Kondisi tersebut menjadi ancaman serius bagi usaha pertanian. Setiap tahun diperkirakan 300.000 ha lahan sawah mengalami kerusakan akibat banjir, dan 60.000 ha di antaranya mengalami gagal panen di Indonesia (Manikmas, 2008).

Banjir yang terjadi di Sulawesi Utara, khususnya di wilayah lumbung padi di 
Sulawesi Utara, diperkirakan menggenangi lahan sawah dengan ketinggian 1-1.5 meter sampai tahun 2013.Lahan sawah yang tergenang diperkirakan sekitar ratusan hektar, yaitu di Dumoga Utara akibat meluapnya Sungai Ongkag yang terhalang tebing batu Langsikan (Noor, 2013).

Respon tanaman padi yang paling peka dalam banjir terjadi pada fase vegetatif, yakni sekitar 1 minggu setelah ditanam (Yulianida et al., 2014). Tahap pemanjangan batang berlangsung sebelum pembentukan malai atau pada tahap akhir pembentukan anakan, sehingga ada periode tumpang tindih dari tahap 2 dan 3. Jumlah daun dan tinggi tanaman anakan terus meningkat. Periode waktu pertumbuhan berkorelasi dengan pemanjangan batang, yaitu batang lebih panjang pada varietas dengan pertumbuhan yang lebih lama.

Fase vegetatif awal merupakan fase vegetatif tumbuh cepat, sehingga tinggi tanaman yang mengalami banjir akan terus bertumbuh. Sehingga tanaman padi yang mengalami banjir akan tetap bertambah tingginya walaupun dalam keadaan tergenang banjir (Ikhwani, 2013).

Banjir menyebabkan permukaan daun akan terselimuti air sehingga akan membuat menguningnya daun (senescene) yang tentunya akan menghambat fiksasi karbon dalam proses fotosintesis pada saat maupun setelah banjir. Ketika fiksasi karbon terhambat fotosintesis pun berkurang akan membuat daun menjadi rusak (Ikhwani, 2013).

Pengaruh banjir terhadap seluruh bagian tanaman belum banyak diteliti. Respon morfologi dan fisiologi tanaman terhadap banjir tersebut berbeda menurut lama waktu rendaman banjir, fase tanaman sewaktu menerima rendaman, dan kekeruhan air rendaman. Respon terhadap banjir dapat berupa besarnya penurunan hasil, bertambahnya umur tanaman atau lambat panen dan perubahan komponen pertumbuhan tanaman dan komponen hasil (Ikhwani, 2013).

Kajian sifat stress padi terhadap rendaman pada fase vegetatif masih kurang dilakukan pada padi lokal Sulawesi Utara, seperti Superwin, Ombong, Temo, dan Burungan. Oleh sebab itu, dalam upaya mencari metode seleksi padi tahan banjir dan alokasi biomassa pada padi lokal Sulawesi
Utara sebagai respon terhadap cekaman rendaman banjir dalam penelitian ini.

\section{METODE \\ Waktu dan Tempat Penelitian}

Peneltitian ini dilaksanakan selama 9 minggu di rumah kaca di Kelurahan Tingkulu, Manado, Sulawesi Utara dan Laboratorium Ekologi Jurusan Biologi FMIPA Universitas Sam Ratulangi.

\section{Alat dan Bahan}

Bahan yang digunakan dalam penelitian ini adalah padi lokal Sulawesi Utara (varietas Superwin, Ombong, Temo dan Burungan), tanah, garam, larutan pemutih komersial, pupuk NPK dan Gandasil-D, dan air.

Alat yang digunakan yaitu botol air mineral ukuran $600 \mathrm{ml}$, kantong plastik, ember, gayung, sekop kecil, pinset, spidol putih, meteran, hot plate dan timbangan analitik. Tanaman padi ditanam pada media berupa tanah campuran (tanah taman:pupuk kandang:sekam $=5: 1: 1$ ), pupuk NPK dengan perbandingan dalam $6 \mathrm{~g}$ pupuk NPK dicampur dengan $7 \mathrm{~kg}$ tanah campuran (modifikasi dari Palit et al., 2015).

\section{Cara Kerja}

Tahapan kerja dalam penelitian ini meliputi seleksi benih, perkecambahan benih, pemeliharaan tanaman, pemberian cekaman banjir, pengambilan data.

Seleksi benih dilakukan dengan cara benih direndam di dalam air garam selama 2 jam dengan tujuan untuk mendapatkan benih yang berkualitas. Benih padi disterilisasi dengan menggunakan pemutih komersial $2 \%$ selama 2 menit dengan 3 kali ulangan, kemudian dicuci dengan air yang sudah dimasak. Selanjutnya benih dikecambahkan selama 3 hari di wadah yang berisi media pasir, dan bagian atas wadah ditutup dengan kertas koran yang sudah dibasahi. Sebelum penanaman, tiap pot yang telah berisi tanah disiram dengan air sampai kapasitas lapang (Nio dan Ludong, 2013).

Benih yang telah berkecambah ditanam pada media tanam dalam pot botol air mineral. Pada tiap pot ditanam 1 biji yang telah berkecambah, selanjutnya disiram dengan campuran air dan pupuk (10 g pupuk 
Gandasil D dalam 10 L air) sampai kapasitas lapang setiap 2 hari. Penyiraman tanaman sampai kapasitas lapang terus dilakukan sampai tanaman minimal mencapai tahap 4 daun yang berkembang penuh atau 4- fullyexpanded leaf (Nio dan Ludong, 2013) dan perlakuan perendaman dimulai setelah tanaman berusia 2 minggu denagn 12 kali ulangan. Pot dan tanamannya dimasukkan ke dalam bak air yang berisi air, sehingga tanaman terendam setinggi $30 \mathrm{~cm}$ di atas permukaan media. Perlakuan banjir terhadap tanaman padi Superwin, Ombong, Temo dan Burungan berlangsung selama 10, 15 dan 20

hari. Pengambilan data pengamatan dilakukan pada hari ke-0 (sebelum perlakuan banjir dimulai), 10, 15 dan 20 hari setelah perendaman

Parameter yang diamati meliputi:

1. Tinggi tanaman.

Tinggi tanaman ini diukur mulai pangkal tanaman sampai daun terpanjang (Hermanasari et al., 2011) padahari ke-0 (sebelum perlakuan banjir dimulai), 10, 15 dan 20 hari setelah perendaman.

2. Jumlah daun

Kerusakan daun dihitung dari jumlah daun tanaman yang menguning atau rusak akibat banjir pada hari ke-0 (sebelum perlakuan rendaman dimulai), 10, 15 dan 20 hari setelah banjir. (modifikasilkhwani et al., 2010).

\section{HASIL DAN PEMBAHASAN Tinggi Tanaman}

Pertumbuhan tanaman $\begin{array}{r}\text { digunakan } \\ \text { mengetahui }\end{array}$
sebagai indikator untuk hubungannya
karakteristik tanaman dan huban
dengan faktor lingkungan. Tanaman padi
membutuhkan volume air yang berbeda-beda
untuk setiap fase pertumbuhannya. Hasil
analisis sidik ragam menunjukkan bahwa
faktor lama perendaman banjir, varietas dan
interaksi keduanya tidak menyebabkan
perbedaan tinggi tanaman yang nyata,
sehingga tidak dilanjutkan dengan uji BNT
5\%. Pertumbuhan padi lokal Sulawesi Utara
(Superwin, Ombong, Temo dan Burungan)
sebelum terendam banjir sampai 20 hari
setelah perendaman adalah kontinu (Gambar
1). Pengaruh waktu banjir menyebabkan
tinggi tanaman tumbuh lebih cepat (Ikhwani,

2010), tetapi tinggi tanaman yang mengalami banjir menunjukkan nilai rata-rata pertumbuhan tinggi tanaman padi yang tidak jauh berbeda antara satu dengan yang lainnya (Rivaldi et al., 2015). Menurut Singh et al., (2011) cekaman rendaman banjir stagnan dengan ketinggian air $30 \mathrm{~cm}$ dan $50 \mathrm{~cm}$ menyebabkan pertambahan tinggi tanaman masing-masing sebesar $13 \%$ dan $17 \%$. Bailey-Serres (2008) melaporkan bahwa cekaman banjir menyebabkan kandungan etilen dan asam giberelat (GA) meningkat sehingga memacu pertambahan tinggi tanaman.

\section{Jumlah Daun}

Dari data yang diperoleh, jumlah daun dari tiap varietas padi lokal Sulawesi Utara memiliki jumlah daun yang beragam. Dari grafik yang ada dapat kita peroleh bahwa jumlah daun pada hari sebelum banjir lebih banyak dibandingkan jumlah daun setelah padi terendam. Namun pada hari ke-20 tiap varietas mengalami pertamabahan jumlah daun walaupun tidak signifikan. Karena setelah 20 hari terendam daun dari tiap varietas ada yang telah tumbuh di atas permukaan rendaman banjir sehingga memungkinkan tanaman menerima cahaya yang cukup sehingga dapat berfotosintesis dengan cukup untuk menghasilkan daun yang baru bagi tanaman padi yang ada.

Hasil penelitian ini menunjukkan bahwa interaksi antara varietas dan perlakuan perendaman banjir melalui uji sidik ragam menyebabkan perbedaan jumlah daun yang signifikan, sehingga dilanjutkan dengan uji BNT 5\%. Pada hari ke-0 rata-rata jumlah daun pada padi varietas Superwin sebanyak 22,083 daun, varietas Ombong 8 daun, varietas Temo 11,083 daun dan varietas Burungan 9,916 daun. Pada hari ke-10 setelah banjir padi varietas Superwin ratarata memiliki jumlah daun sebanyak 10,25 daun, varietas Ombong 4,75 daun, varietas Temo 6 daun dan varietas Burungan 7,25 daun. Pada hari ke-15 rata-rata jumlah daun padi varietas Superwin sebanyak 11,416 daun, varietas Ombong 4,916 daun dan varietas Burungan 7,083 daun. Pada hari ke20 padi varietas Superwin memiliki rata-rata jumlah daun sebanyak 14,333 daun, varietas Ombong 4,916 daun, varietas Temo 7 daun dan varietas Burungan 8,583 daun. Pada saat 
recovery rata-rata jumlah daun padi varietas Superwin yaitu 11,25 daun, varietas Ombong
$5,416 \mathrm{~cm}$, varietas Temo $7,416 \mathrm{~cm}$ dan varietas Burungan 7,5 daun (Gambar 2).

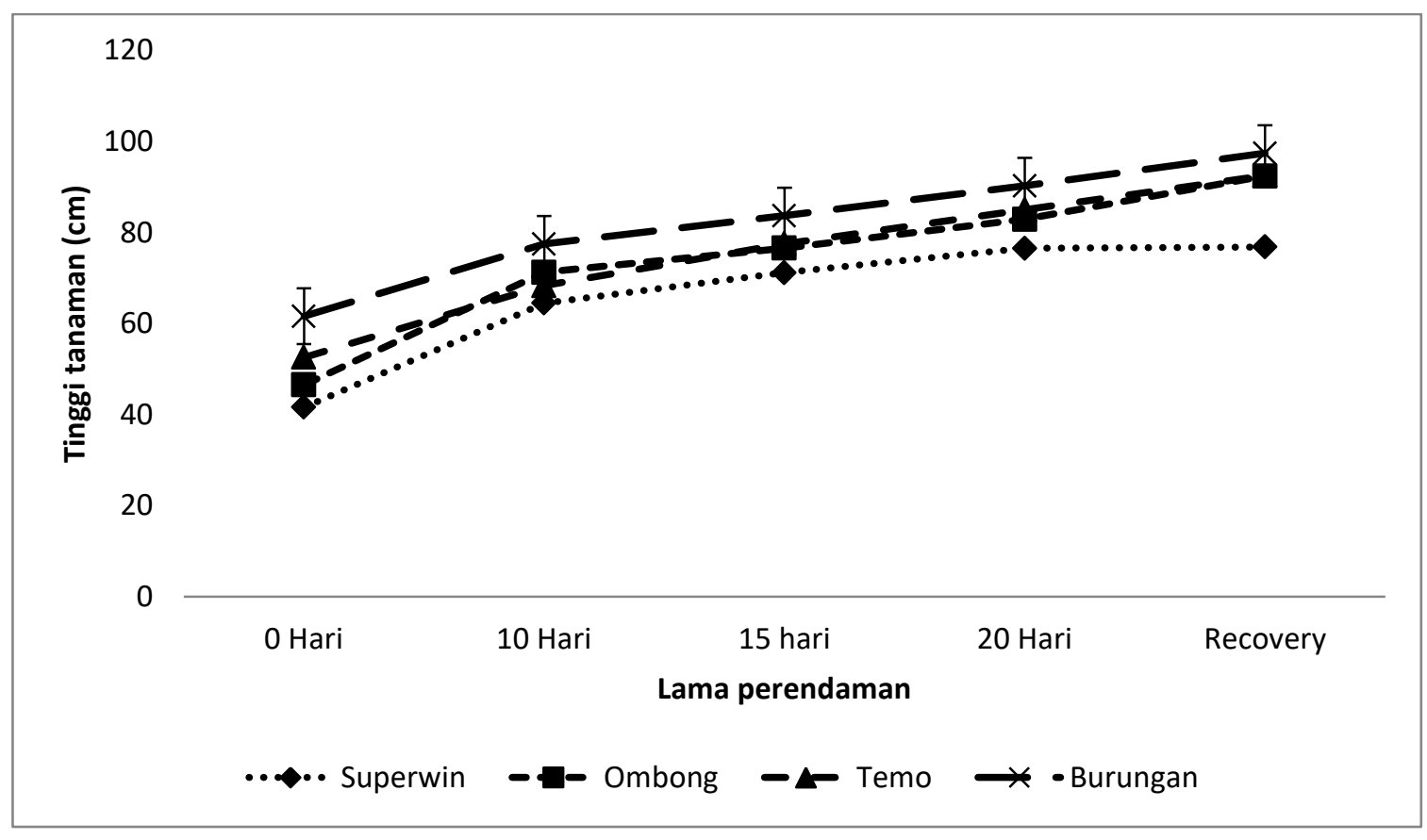

Gambar 1.Tinggi tanaman padi varietas Superwin, Temo, Ombong, Burungan yang diberi perlakuan selama $0,10,15$ dan 20 hari perendaman banjir serta 1 minggu setelah recovery.

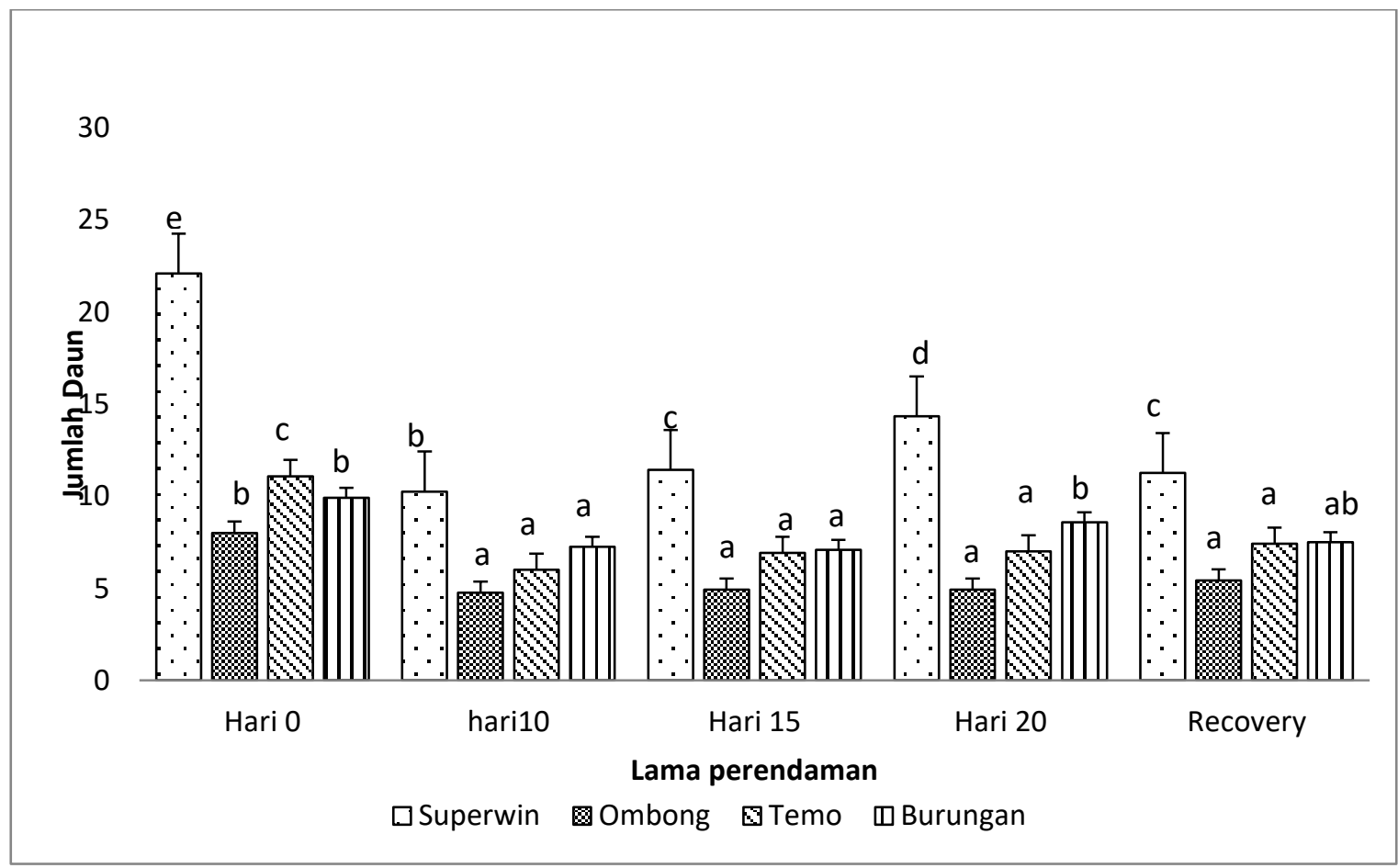

Gambar 2. Jumlah daun padi varietas Superwin, Temo, Ombong, Burungan yang diberi perlakuan selama $0,10,15$ dan 20 hari perendaman banjir serta setelah 1 minggu recovery. Huruf yang berbeda menunjukkan jumlah daun berbeda nyata berdasarkan uji BNT $5 \%$. 
Hasil uji BNT 5\% menunjukkan padi varietas Superwin memiliki jumlah daun terbanyak sebnayak 20 helai daun, padi varietas Ombong memiliki daun terbanyak 8 helai daun, padi varietas Temo memiliki daun terbanyak sebanyak 11 helai dan padi varietas Burungan memiliki daun terbanyak, yaitu 9 helai daun. Dari notasi uji BNT 5\% terlihat bahwa pada hari ke-10 setelah terendam banjir jumlah daun varietas Ombong, Temo dan Burungan tidak berbeda signifikan dengan hari ke-15 setelah terendam banjir dan juga dengan padi varietas Ombong dan Temo pada hari ke-20 terendam dan pasca terendam (recovery). Dari data ini dapat dijelaskan bahwa padi varietas Ombong dan Temo memakai strategi pertama atau strategi diam untuk bisa bertahan hidup (Hattori et al., 2011). Jumlah daun padi hari ke-0 berbeda nyata dengan hari yang lain, ini dikarenakan varietas padi lokal Sulawesi Utara belum mengalami perlakuan atau belum dibanjiri sehingga belum mengalami keruskan setelah direndam (Gambar 2). Padi varietas selain Superwin memiliki jumlah dauh yang tidak berbeda nyata dari hari ke-0 hingga setelah banjir. Adapun varietas superwin mengalami perbedaan nyata jumlah daun setelah direndam banjir dari hari sebelum direndam banjir. Jumlah daun yang sedikit ini akan menghambat fotosintesis sehingga ketika padi yang terendam banjir tidak mengalami fotosintesis akan mati. Dibanding dengan varietas lain superwin adalah padi yang memiliki tinggi tanaman terpendek daripada padi lokal Sulawesi Utara yang lain. Sehingga padi superwin ini ketika mengalami banjir sulit berfotosintesis karena daunnya yang terendam sulit mengalami fotosintesis dan membuat daunnya cepat rusak.

Berdasarkan hasil penelitian ini, interaksi antara varietas dan lama pernedaman banjir berpengaruh nyata, sehingga jumlah daun bisa dijadikan indikator tanaman yang tahan terhadap banjir. Jumlah daun yang semakin sedikit akan mengindikasikan bahwa tanaman padi yang terendam banjir akan sulit berfotosintesis dan akibatnya tanaman bisa mati.

\section{KESIMPULAN}

Tinggi tanaman dapat dijadikan indikator sebagai padi lokal Sulawesi Utara toleran terhadap cekaman banjir yang mampu bertahan dan tumbuh baik baik varietas Burungan, Ombong, Temo dan Superwin.

Berdasarkan jumlah daun dari keempat varietas varietas Superwin sebagai padi sawah memiliki daun yang berbeda nyata dengan ketiga varietas lainnya saat sebelum direndam, secara keseluruhan dari jumlah daun setiap varietas bisa bertahan dalam rendaman banjir sehingga pun bisa dijadikan sebagai indikator padi yang tahan banjir.

\section{DAFTAR PUSTAKA}

Hermanasari, R, H. Supartopo dan B. Kustianto. 2011. Galur Harapan Padi Rawa Toleran. Penelitian Pertanian Tanaman Pangan vol 30 No.2 2011: 71-75.

Ikhwani. 2013. Ketahanan Varietas Padi Toleran Rendaman dan Responnya terhadap Pemupukan .Jurnal Lahan Suboptimal ISSN: 2252-6188 (Print), ISSN: 2302-3015.

Nio, S.A dan D.P.M. Ludong 2013.Comparing the drought tolerance of local rice cultivar Superwin with other cultivars cultivated in North Sulawesi Province based on dry matter partitioning. 4th International Conference of Global Resource Conservation.

Noor, $\quad$ R. 2013 http://manado.tribunnews.com/2013/0 8/09/hujan-deras-dumoga-lumbungpadi-sulut-banjir Diakses kamis 28 juli 2016 pkl 12:10.

Palit, E.J., S. A. Nio dan F.R. Mantiri. 2015. Pelayuan daun pada padi local Sulut saat kekeringan. Jurnal MIPA UNSRAT Online 4(2):120-124.

Rivaldi. 2015. Pertumbuhan dan hasil padi (oryza sativa L.) salibu varietas hibridapada tinggi dan waktu penggenangan. Jurnal Pertanian Fakultas pertanian Universitas Tamansiswa. Padang. 
Singh, S., D.J. Mackill dan A.M. Ismail. 2011. Tolerance of longer-term partial stagnant flooding is independent of the Sub1 locus in rice. J. Field Crops Res. 121:311-323.

Yulianida, S.,W. Ardie, Suwarno dan H. Aswidinnor. 2014. Respon dan produktifitas padi rawa terhadap cekaman rendaman stagnan untuk pengembangan di lahan rawa lebak. J. Agron Indonesia 43 (1) : 15 - 22 (2015). IPB. Bogor 